\section{Ethical Lingua}

Journal of Language Teaching and Literature

ISSN 2355-3448 (Print)

ISSN 2540-9190 (Online)

Volume 6, Number 2, August 2019

pp. $86-97$

\title{
The Betterment of Group Dynamics
}

\section{in Theory of Translation Class through Lesson Study}

\author{
Magfirah Thayyib \\ magfirah_thayyib@iainpalopo.ac.id \\ Institut Agama Islam Negeri (IAIN) Palopo, Indonesia \\ Received : 15 July 2019; Accepted: 21 August 2019 \\ $\mathrm{DOI}$ \\ : https://doi.org/10.30605/25409190.v6.86-97
}

\begin{abstract}
The understanding of group dynamics is a challenging field. It is quite often that the interaction and energy between students in the group present in negative pattern or less healthy. Lesson study is considered to be a suitable way to cope with that group dynamics problem. The objectives of this research are to describe the pattern of group dynamics in Theory of Translation class and outline the efforts done for the betterment of group dynamics through Lesson Study. The research was conducted in class 3A of third semester of English Language Education Study Program. The data of group dynamics were obtained from the observers' sheets. While the data of the efforts done for the betterment of group dynamics were obtained from plan and reflection discussion notes, and a checklist of application. In analyzing the data, the first data were presented descriptively and made into inferences. The second data were grouped and described; then their effectiveness was analyzed qualitatively. Based on the result of the research, it is found that the group dynamics in Theory of Translation class from open class $1-4$ went through a betterment. The efforts done for the betterment of group dynamics were distributing job and responsibility within group, delivering the whole instruction of group activities in the beginning and checking for students understanding, and providing worksheet for group work and learning media for each group.
\end{abstract}

Keywords: group dynamics; theory of translation, lesson study 


\section{Introduction}

Group dynamics focuses on the scientific analysis of group behavior (Dornyei \& Malderez, 1997). Group dynamics is the dynamics of the learner group, its characteristics, and evolution that determine the climate of the classroom (Dornyei \& Murphey, 2003). In a simple word, group dynamics means a change of behavior through interaction in group. The interaction includes deriving, choosing, negotiating, and executing result, and is patterned by rule, norm, interpersonal relation of group members (Thomson, 2006). A group becomes a medium to carry out the learning objective, gives support and direction during the learning process, and offers fun way to acquire knowledge and skill (Langevin, 2014). Thus, group dynamics develop in line with the history of the group or 'the record of the group pattern.'

According to Tuckman \& Jensen (in Dornyei \& Malderez, 1997), there are five (5) stages of group development that are relevant to the context of classroom. Stage 1 Forming: the beginning of group formation that characterized by the awkward feeling of the group members to interact and they tend to be silent. Stage 2 Storming: characterized by a conflict in which the group members express individuality and disagreement in which idea is criticized and speaker is interrupted. Stage 3 Norming: the group becomes more cohesive, the students help one another to achieve the goal; they start to accept their norm and rule as a group. Stage 4 Performing: characterized by emotion decrease and cooperation increase that enable problem-solving and or solution executing. Stage 5 Adjourning: the end of group work.

A positive or healthy group dynamics is the characteristic of a successful group (Heron in Galajda, 2012). A group should be oriented toward task and process. Generally, it means that the students work together, but the group still has to be oriented to individual work. In a successful group, the students know how to get involved in joint work and also are able to concentrate on their individual task. In fact, group dynamics in learning process sometimes has negative pattern or in other word is less healthy. In group, there might be a member who does not actively participate; conversely another member might dominate the working of the task. The workload is not well distributed, so the learner's understanding is not developed by the group activities done. This problem is usually missed from teacher's notice.

The understanding of group dynamics is indeed a challenging field. Enhancing a healthy group dynamics is beneficial for the success of the teaching-learning process. A healthy group dynamics itself in collaborative learning needs to be facilitated. Nazari \& Willis (2014) has investigated what constitute a good group dynamics from postgraduate students' perspective. Scholten \& Verkroost (2016) exposed the activities to stimulate and support the 
Thayyib:

The Betterment of Group Dynamics in Theory of Translation Class through Lesson Study

group work of international students. Similarly, Quy (2017) offered bonding activities to promote an atmosphere of group work in English as a Foreign Language (EFL) classroom. While, Alikhani \& Bagheridoust (2017) investigated the effect of group-dynamics instruction on EFL learners. Theobald, et al. (2017) explored how group dynamics impact university students' learning.

This research of group dynamics in Theory of Translation class is done through Lesson Study, which also sets out collaborative learning. Lesson Study is a specified form of classroom action research focusing on the development of teacher practice knowledge (Dudley, 2011). It has been in use in Japan since the 1870s. The importance in group dynamics which deals with the students' involvement in a join work and their concentration on individual task accords with one of the aspects emphasized in Lesson Study. The recommendation of collaborative learning in Lesson Study enables mutual appreciation, grows creativity and freedom for the learners to have self-understanding (Supriatna, 2014). The learning activities designed through Lesson Study boosted students in both individual and group learning (Syam \& Thayyib, 2015).

Specifically, the research questions investigated through this Lesson Study program are 1) How is the pattern of the group dynamics that happened in the learning of Theory of Translation?; 2) What are the efforts done for the betterment of group dynamics in the learning of Theory of Translation? The elaboration for these research question provides a new insight for group dynamics in teaching and learning process because it was done through Lesson Study by involving "group" of lecturers in all of its stages (plan, do, see) (Dudley, 2011). A Lesson Study consists of a cycle of at least three 'research lessons' that are jointly planned, taught/observed and analyzed by a Lesson Study group. In Lesson Study, instructor teams shared experiences and ideas related to teaching and learning (Coenders \& Verhoef, 2018).

\section{Method}

Lesson Study was applied in Theory of Translation subject at class $3 \mathrm{~A}$ of English Education Study Program. There were 39 students who enrolled in the subject that had been divided into eight (8) permanent groups at the beginning of the course. The numbers of the members in each group were 6,5 , and 4 . The application of Lesson Study in Theory of Translation learning was done in 4 cycles successively in the 7th, 9th, 10th, and 11th meeting since the group activities have been done intensively in those meetings.

Through that Lesson Study application, the data of the pattern of group dynamics were obtained from the observation sheet of the observers while the data of the efforts done for the betterment of group dynamics were obtained from the notes of plan and see discussion and a checklist of the application of those efforts in the learning process. 
Subsequently, the data of the pattern of group dynamics were presented descriptively and made into inferences. While the data of the efforts done for the betterment of the group dynamics were grouped and described; then the effectiveness of those efforts was analyzed qualitatively.

\section{Results}

\section{Cycle 1}

\section{Plan}

The material of open class in cycle 1 was "translation of literary work." The steps of learning proposed by the (model) lecturer in lesson design were considered good and agreed by other lecturers who attend the plan discussion. One suggestion given by one observer was the proper setting of time allocation so every step of learning could be carried out well, and the objective could be obtained.

\section{Do}

The learning activity began with brainstorming of literary work theory which consists of a definition, kinds, and aspects of literary work. It was followed by interactive discussion about theories and steps in translating literary work. In the next activity, the groups of students were directed to read, analyze, and translate the given English poem into Indonesian.

Then, each group presented the result of their poem translation. The representatives of each group read the English poem, explained the meaning, and then read the Indonesian translation of the poem. While one group having the presentation, the other students/groups listen. After that, they were given a chance to comment on the translation of the poem. The lecturer also gave general comment on each poem translation.

\section{See}

All observers stated that most of the students had learned well and there were still few of them who were busy with their notebooks at the beginning of the learning process. At the time of group discussion, almost all groups were active in doing interaction; all of the students were active to deliver their ideas in their group discussion. However, there were few groups that experience confusion and the working of the task was dominated only by one member of the group.

\section{Cycle 2}

\section{Plan}

The material of open class in cycle 2 was "proposition and its translation". There was one learning step added in lesson design through plan discussion. The step suggested by the observer was the presentation of the example of 
Thayyib:

The Betterment of Group Dynamics in Theory of Translation Class through Lesson Study

student individual translation to be analyzed together in class. That closing step was expected to reinforce the learning material.

Do

The students' activity began with an interactive discussion of "definition, structure, and kinds of proposition." The students, then, were directed to do semi-jigsaw activity. In their origin (permanent) groups, the students analyzed number of given propositions/sentences and translated them. Next, the students formed new (expert) groups and discussed the result of the translation from the original groups. After that, the students went back to their original groups and re-discussed the discussion result from the new groups.

After the jigsaw activity finished, each group was given a chance to share the sentences that they considered difficult to be translated. The last learning step was actually translating friend's paragraph but it was not done in the classroom because of time limitation. That individual activity was given as homework.

\section{See}

In see phase, several weaknesses of group activity in the form semi-jigsaw were discussed together. There was a group member who dominated the discussion, there was a student who was active in his origin group but tended to be passive in his new group. Other weaknesses were related to the limitation of discussion time and the noise of group movements.

\section{Cycle 3}

\section{Plan}

The open class in cycle 3 dealt with the practical follow-up of "principles of translation" material. The observers who attended the Plan phase suggested the lecturer to clarify the assessment rubric that would be used by the students in group activity and added a closing step of the learning. At the end of the learning, the best group translation should be showed and discussed in the class. Those two suggestions were accepted by the lecturer.

Do

The learning activity began with the review of "principles of translation". Then, the students translated a determined advertisement video in group. After finished, the students (in group) moved from one group to another group (rotated) to assess and write comments on other groups' translations.

The groups of students, then, went back to their group position and revised their translation based on the assessments and comments from other groups. Last, the group that achieved higher translation score presented their advertisement video translation. It was as the suggestion given by one of the observers in Plan phase. 
See

Based on the comments of the observers, the learning process ran well. Few technical obstacles that influenced the group activity were put forward by the observers. When doing group rotation, some of the students were confused because they did not understand the instruction. Using a laptop in each group to show the advertisement video was constrained by low audio quality and insufficient battery life.

\section{Cycle 4}

\section{Plan}

The material of open class in cycle 4 was the practice of "translation of literary work." The lesson design proposed in plan discussion by the lecturer was considered good enough by the observers. The lecturer was only asked to strengthen the connection between "translation of literary work" material that had been presented in the previous meeting and the practice that would be done at the beginning of the lesson.

\section{Do}

All of the learning stages that considered good in the plan discussion were completed in do phase. The students were first asked to do brainstorming related to the steps in translating literary work. It was done to connect the material with the previous meeting's material as suggested by the observers in plan discussion. Next, the students in groups translated a song determined. They, then, sang the translated song in front of the class.

When one group presented/sang the song, other groups had to listen and gave a score on the assessment sheet given. After one group presentation is done, one representative of another group who assesses the presentation was given chance to comment.

\section{See}

In see discussion, the observers expressed that generally, the learning ran well and very interesting. But there was a fact that, when one group sang their translated song in front of the class, some of the members of the groups who did not perform did not pay attention to the performer. They were busy with other things like practice to sing their own song.

\section{Discussion}

\section{The Pattern of Group Dynamics}

From the data of the observers' observation sheets, the patterns of group dynamics happened in the learning process of each open class of Theory of Translation are elaborated in the following table: 
Thayyib:

The Betterment of Group Dynamics in Theory of Translation Class through Lesson Study

Table 1. The Pattern of Group Dynamics

\begin{tabular}{|c|c|c|}
\hline $\begin{array}{l}\text { Open } \\
\text { Class }\end{array}$ & Group Activity & The Pattern of Group Dynamics * \\
\hline \multirow{3}{*}{1} & \multirow{3}{*}{$\begin{array}{l}\text { Translating a poem } \\
\text { and presenting the } \\
\text { translated poem }\end{array}$} & $\begin{array}{l}\text { 1) The group interaction was good enough, active, and } \\
\text { collaborative. }\end{array}$ \\
\hline & & $\begin{array}{l}\text { 2) Almost all groups interacted well; there was one group } \\
\text { which the discussion was dominated by one member } \\
\text { only. }\end{array}$ \\
\hline & & $\begin{array}{l}\text { 3) All of the members of } 8 \text { groups were active in delivering } \\
\text { their ideas; giving appreciation by paying attention on } \\
\text { other groups' presentation. }\end{array}$ \\
\hline \multirow{3}{*}{2} & \multirow{3}{*}{$\begin{array}{l}\text { Translating number of } \\
\text { sentences with various } \\
\text { propositions } \\
\text { (semi-jigsaw activity) }\end{array}$} & $\begin{array}{l}\text { 1) There was one group which the discussion ran well } \\
\text { because the leader of the group did good job; there } \\
\text { were groups that dominated by one or two member(s), } \\
\text { the others were passive; there was a group that finally } \\
\text { determined the ideal translation by voting because the } \\
\text { discussion was complicated. }\end{array}$ \\
\hline & & $\begin{array}{l}\text { 2) There was a group that dominated by one or two } \\
\text { member(s) only, the other members were passive; } \\
\text { there was a student who was not comfortable to join the } \\
\text { discussion in the new group. }\end{array}$ \\
\hline & & $\begin{array}{l}\text { 3) All of the students actively did the task according to the } \\
\text { lecturer's instruction. }\end{array}$ \\
\hline \multirow{2}{*}{3} & \multirow{2}{*}{$\begin{array}{l}\text { Translating } \\
\text { advertisement video } \\
\text { and assessing the } \\
\text { other groups' } \\
\text { translation }\end{array}$} & $\begin{array}{l}\text { 1) There was one group that still confused with the } \\
\text { instruction given by the lecturer; there was one group } \\
\text { which the work was hampered by the small audio of the } \\
\text { notebook. }\end{array}$ \\
\hline & & $\begin{array}{l}\text { 2) There was one group that still confused with the } \\
\text { instruction given by the lecturer; there was one group } \\
\text { which the work was hampered by the notebook's audio } \\
\text { but they did not complain it. }\end{array}$ \\
\hline \multirow[b]{2}{*}{4} & \multirow{2}{*}{$\begin{array}{l}\text { Translating a song and } \\
\text { singing the translated } \\
\text { version, assessing and } \\
\text { commenting on other } \\
\text { groups' performance }\end{array}$} & $\begin{array}{l}\text { 1) The students were very enthusiastic in following the } \\
\text { lesson; some students did not pay attention on other's } \\
\text { group performance. }\end{array}$ \\
\hline & & $\begin{array}{l}\text { 2) The students were very enthusiastic in following the } \\
\text { lesson because the material was very interesting; the } \\
\text { member of the group did not focus on the other group } \\
\text { performance and did the assessment task. }\end{array}$ \\
\hline
\end{tabular}

*based on the observers' code: 1), 2), 3)

Based on the details in table 1, in open class 1, the group dynamics of most of the groups observed were healthy enough. However, there was one group whose discussion was still dominated by one member. It means that its group dynamics were less healthy. Jaimini (2014) stated that group discussion should be carried out by giving chance to all of the group members. 
Various patterns of group dynamics were observed in open class 2 . There was a group with a positive dynamics pattern because the leader of the group did his function properly in managing the running of the discussion and he did not boss the group. There were several groups with less healthy dynamics because there was a domination of one or two member(s) of the group while other members were passive in the discussion and task completion.

There was a slightly unique pattern of group dynamics in open class 2 in which there was one group that did voting to finish their debate. This pattern can be categorized as negative dynamics because, in an effective group, the decision is made through a discussion/deliberation. It is in accord with Thomson's (2006) that the pattern of group interaction is a negotiation/deliberation, not voting.

In open class 2 also, there was a student who did feel comfortable in doing discussion with his new group (in a semi-jigsaw model). This is considered a natural thing by referring to the theory of Tuckman \& Jensen's stages (in Dornyei \& Malderez, 1997). In stage 1 (forming), the group members usually feel awkward to interact in a newly-formed group.

The dynamics pattern of all groups in open class 3 was good enough though at first it was constrained by the students' confusion toward the lecturer's instruction. When the group activity was taking place, the students were also hampered by technical problem due to the notebooks they used, but they did not complain about it. The group of students in such state seemed to be in stage 3 (norming) of Tuckman \& Jensen's theory in which the students help each other to attain the objective.

In open class 4, the students were too enthusiastic with their group performance (singing translated song), so they tended to ignore another associative task, assessing other groups' translation and performance. The students in groups seemed to complete one task optimally along with the development of their group to stage 4 (performing) of Tuckman \& Jensen's theory. The pattern of this group dynamics looked as if it was positive and negative at the same time.

If a pattern line is drawn from open class $1-4$, the group dynamics seemed to change to a more positive way (betterment). Group interaction in the form of discussion and task completion became better in open class 3 and 4 . This is related to group solidarity composed through frequency the students work together in permanent group. In "a healthy group", first bonding is periodically replaced by an interpersonal relation which is deeper and firmer so-called "acceptance" (Dornyei \& Murphey, 2003).

\section{The Efforts Done for the Betterment of Group Dynamics}

The betterment of group dynamics from open class $1-4$, as mentioned before, for sure, was actualized by the significant efforts done both as process 
Thayyib:

The Betterment of Group Dynamics in Theory of Translation Class through Lesson Study

and result from all stages of Lesson Study. The data of the efforts done for the betterment of group dynamics based on the notes in plan and see discussions are presented in the table below:

Table 2. The Efforts for The Betterment of Group Dynamics

\begin{tabular}{|c|c|c|c|c|}
\hline \multicolumn{3}{|r|}{ Efforts suggested* } & \multicolumn{2}{|r|}{ Efforts done ${ }^{\star \star}$} \\
\hline See 1 & 1) & $\begin{array}{l}\text { There should be job and } \\
\text { responsibility distribution in } \\
\text { group. }\end{array}$ & $\begin{array}{l}\text { Open } \\
\text { class } 2\end{array}$ & $\begin{array}{l}\sqrt{ } \text { Job distribution in group was } \\
\text { accomplished in the form of } \\
\text { semi-jigsaw interaction. }\end{array}$ \\
\hline \multirow{2}{*}{ See 2} & 1) & $\begin{array}{l}\text { Special approach should be } \\
\text { given to students who are } \\
\text { less active in group work. }\end{array}$ & \multirow{3}{*}{$\begin{array}{l}\text { Open } \\
\text { class } 3\end{array}$} & $\begin{array}{l}\text { x There was no special approach } \\
\text { done because all students were } \\
\text { active in group. }\end{array}$ \\
\hline & 2) & $\begin{array}{l}\text { Whole instructions of group } \\
\text { activity should be given in the } \\
\text { beginning. }\end{array}$ & & $\begin{array}{l}\sqrt{ } \text { Whole instructions had been given } \\
\text { in the beginning but it still caused } \\
\text { confusion. }\end{array}$ \\
\hline Plan 3 & 1) & $\begin{array}{l}\text { The rubric of assessment for } \\
\text { group assessment activity } \\
\text { should be clarified. }\end{array}$ & & $\begin{array}{l}\sqrt{ } \text { The rubric of assessment had } \\
\text { been prepared and given to the } \\
\text { groups of students. }\end{array}$ \\
\hline & 1) & $\begin{array}{l}\text { The learning media should } \\
\text { be prepared. }\end{array}$ & \multirow{3}{*}{$\begin{array}{l}\text { Open } \\
\text { class } 4\end{array}$} & $\begin{array}{l}\sqrt{ } \text { Projector and notebook were } \\
\text { available. }\end{array}$ \\
\hline See 3 & 2) & $\begin{array}{l}\text { The lecturer should check the } \\
\text { students' understanding } \\
\text { toward the instruction of } \\
\text { group work given. }\end{array}$ & & $\begin{array}{l}\sqrt{ } \text { Explanation and check of } \\
\text { instruction understanding were } \\
\text { done before group work. }\end{array}$ \\
\hline Plan 4 & 1) & $\begin{array}{l}\text { The text of original and } \\
\text { translated song should be } \\
\text { given for each student. }\end{array}$ & & $\begin{array}{l}\mathrm{x} \text { The text of translated song was } \\
\text { only showed using projector. }\end{array}$ \\
\hline \multirow{2}{*}{ See 4} & 1) & $\begin{array}{l}\text { Group works should be } \\
\text { integrated and compendious. }\end{array}$ & & \multirow{2}{*}{ for the next learning } \\
\hline & 2) & $\begin{array}{l}\text { Worksheet should be given } \\
\text { for each student in group. }\end{array}$ & & \\
\hline
\end{tabular}

*based on observers' code: 1), 2), 3); ${ }^{* *} \sqrt{ }=$ done, $x=$ was not done

There were many learning suggestions proposed in both plan and see discussions in each cycle. However, there were only numbers of them which directly related to the betterment of group dynamics, as shown in the table above.

There were two things suggested due to the betterment of group dynamics that were not completed in the next open class. In See 2, the lecturer was suggested to do special approach to students who are not active in group activity. In open class 3 , the approach was not done because all students were active in group working on advertisement video translation then moved from one group to another group to assess other groups' translation. The suggestion in plan 4 was to prepare text of original song and translated version for each student. That 
suggestion was not done because it was replaced by showing the translated song using projector that seemed helpful enough.

One effort that seemed not plans was the giving of whole instructions in open class 3 . The ineffectiveness probably happened because the instruction to move (rotate from one group to another group) to assess other groups' translation in a new group activity for the students. Beyond that condition, ideally, the rules of group activity that are given in the beginning and received by all the members of the group make group dynamics more positive (Dornyei \& Murphey, 2003).

For the rest, all efforts suggested through Plan and See were done in the learning process and proven effective to fix the group dynamics. In See 1, job and responsibility distribution was suggested then were actualized in the form of semi-jigsaw group activity in open class 2 . This effort was adequately effective because, in the paradigm of collaborative learning, each of group members has to have individual responsibility.

The suggestion in plan 3 to clarify the rubric of group assessment was done in open class 3 . The preparation of the rubric supported the group assessment activity which was intentionally chosen as a part of the learning process. Peer assessment activity can give understanding of socialization skill to group member (Jaimini, 2014). The betterment of group dynamics, of course, can be done by choosing the appropriate type of activity.

Two suggestions in See 3, discussions were also completed in open class 4 namely the preparation of learning media in each group and the check of understanding of group instruction. Both suggestions were confirmed to contribute to the betterment of students' group dynamics in open class 4 . While two suggestions in See 4, discussions can be done in the next learning.

One thing that was done in the learning process to fix the group dynamics was selecting exciting group activity. That selection, undeniably, was resulted from plan and see discussion of Lesson Study. One of the activities that were considered very interesting by the observers was the group competition of song translation and singing performance (of the translated song) in the class. This activity was enabled because in open class 3 and 4 the learning material was in form of translation practice.

\section{Conclusion}

The group dynamics in Theory of Translation learning from open class $1-4$ went through a betterment (a change to be more positive). The efforts done for the betterment of group dynamics were: distributing job and responsibility within the group, delivering the whole instruction of group work at the beginning of group activity, checking for students' understanding toward the instruction, providing worksheet for group work, and preparing learning media for each group. 
Thayyib:

The Betterment of Group Dynamics in Theory of Translation Class through Lesson Study

The lecturer (or lecturer's group discussion) is suggested to adopt Lesson Study activity in solving a problem and improving the learning quality especially the ones related to group dynamics. The lecturer should spend time to observe the learning process happens in group in order to encourage healthy group dynamics. The lecturer should always facilitate group activity done by students from the forming until adjourning stage of the group. The lecturer (or lecturer's group discussion) should provide suitable, integrated, and exciting group activities.

\section{Acknowledgment}

The research was conducted as a part of Lesson Study Program in Faculty of Teacher Training and Education, Universitas Cokroaminoto Palopo (FKIP UNCP), Indonesia. This research has also been presented in World Association of Lesson Studies International Conference 2015 in Thailand.

\section{References}

Alikhani, M., Bagheridoust, E. (2017). The Effect of Group Dynamics-Oriented Instruction on Developing Iranian EFL Learners' Speaking Ability and Willingness to Communicate. English Language Teaching, 10 (11), 44-58.

Coenders, F., Verhoef, N. (2018). Lesson Study: Professional Development for Beginning and Experienced Teachers. Professional Development in Education. https://doi.org/10.1080/19415257.2018.1430050

Dornyei, Z., Malderez, A. (1997). Group Dynamics and Foreign Language Teaching. System, 25(1), 65-81.

Dornyei, Z., Murphey, T. (2003). Group Dynamics in the Language Classroom.

Cambridge: Cambridge University Press.

Dudley, P. (2011). Lesson Study: A Handbook. www.lessonstudy.co.uk.

Galajda, D.. (2012). Teacher's Action Zone in Facilitating Group Dynamics. Lingvarvm Arena, 3 (ANO 2012), 89-101.

Jaimini, N. (2014). Group Dynamics in Collaborative Learning: Contextual Issues and Considerations. Impact, 2(2), 83-88.

Langevin Learning Services. (2014). 5 Instructional Techniques to Promote Positive Group Dinamics. www.langevin.com. 1 December 2014.

Nazari, A., Willis, Kim. (2014). One Big Happy Family? An Investigation into Students'

Perceptions of Group Dynamics on an MA TESOL Program. ELR Journal, 105-128.

Quy, P. (2017). Group Dynamics: Building a Sense of Belonging in the EFL Classroom.

English Teaching Forum, 55(1), 14-21.

Scholten, C., Verkroost, M-J. (2016). Group Dynamics in the International Classroom.

Paper Presented in Education Day, 27 October 2016. University of Twente, Netherlands.

Supriatna, A. (2014). Etika dan Profesionalisme Pendidik untuk Pendidikan Karakter dalam Implementasi Kurikulum 2013. Paper Presented in Seminar Nasional 
Kurikulum 2013 dan Implementasinya, 3 May 2014.

Syam, R., Thayyib, M. (2015). The Development of Learning Activities in Pronunciation Practice Class through Lesson Study. Ethical Lingua: Journal of Language Teaching and Literature, 2(1), 167-180.

Theobald, E. J., Eddy, S. L., Grunspan, D. Z., Wiggins, B. L., Crowe, A. J. (2017) Student perception of group dynamics predicts individual performance: Comfort and equity matter. PLOS ONE 12(7): e0181336. https://doi.org/10.1371/journal.pone.0181336 Wadsworth, T. (2006). Introduction to Group Dynamics. Star Logo. 